\title{
Improvement of Renewable Bioenergy Production in Microbial Fuel Cells with Saponin Supplementation
}

\author{
Skylar Choi ${ }^{1}$, Yongjin Park2 ${ }^{2}$ Immanuel H. Anaborne ${ }^{3}$, Jin Sik Song4, \\ Ji Woo Han', So Hyun Jeon', Jaewoo Kim7, James Kim, Jinkwon Lee', Paul S. Chung10* \\ ${ }^{1}$ Horace Greeley High School, Chappaqua, NY, USA \\ ${ }^{2}$ Deerfield Academy, Deerfield, MA, USA \\ ${ }^{3}$ Oakton High School, Vienna, VA USA \\ ${ }^{4}$ School of Arts \& Sciences, University of Virginia, Charlottesville, VA, USA \\ ${ }^{5}$ School of Arts \& Sciences, Emory University, Atlanta, GA, USA \\ ${ }^{6}$ Bachelor of Science, Villanova University, Villanova, PA, USA \\ ${ }^{7}$ College of Letters \& Sciences, University of California Los Angeles, Los Angeles, CA, USA \\ ${ }^{8}$ School of Arts \& Sciences, University of Michigan, Ann Arbor, MI, USA \\ ${ }^{9}$ Division of Biological Sciences, Revelle College, University of California, San Diego, CA, USA \\ ${ }^{10}$ Fuzbien Technology Institute, Rockville, MD, USA \\ Email: *paulschung08@gmail.com
}

How to cite this paper: Choi, S., Park, Y.J., Anaborne, I.H., Song, J.S., Han, J.W., Jeon, S.H., Kim, J., Kim, J., Lee, J. and Chung, P.S. (2021) Improvement of Renewable Bioenergy Production in Microbial Fuel Cells with Saponin Supplementation. Journal of Sustainable Bioenergy Systems, 11, 82-93.

https://doi.org/10.4236/jsbs.2021.112006

Received: February 16, 2021

Accepted: June 15, 2021

Published: June 18, 2021

Copyright $\odot 2021$ by author(s) and Scientific Research Publishing Inc. This work is licensed under the Creative Commons Attribution International License (CC BY 4.0).

http://creativecommons.org/licenses/by/4.0/ (c) (i) Open Access

\begin{abstract}
Microbial fuel cell (MFC) is one of renewable biofuel production technology that directly converts biomass to electricity. Cellulosic biomass is particularly attractive renewable resources for its low cost and abundance and neutral carbon balance. However, methanogenesis remains as a major factor limiting MFC performance. The current study reports that saponin addition at $0.05 \%$ $\mathrm{w} / \mathrm{v}$ dose to anolyte in MFCs inhibited methanogenesis and improves power generation and cellulose fermentation. Mediator-less two chamber H-type MFCs were prepared using rumen fluid as anode inocula at $20 \% \mathrm{v} / \mathrm{v}$ of anolyte to convert finely ground pine tree (Avicel) at $2 \%$, w/v to electricity. Saponin was added to the anode of MFC at $0.005 \%$ or $0.05 \% \mathrm{v} / \mathrm{v}$ dosage for treatment. MFC power and current across an external resistor were measured daily for $10 \mathrm{~d}$. On $\mathrm{d} 10$, collected gases from anode compartment were measured for total gas volume and analyzed for gas composition on gas chromatography. Supplementation of saponin to MFC at $0.005 \%$ did not have any effects on electricity generation or biogas production and composition. Saponin at $0.05 \%$ dose reduced $10 \%$ of methane production and increased $40 \%$ of $\mathrm{CO}_{2}$ production and $6.4 \%$ of total gas production for 10d MFC operation. Voltage across resistor prior to treatment addition (d0) was $164.75 \pm 9.07$
\end{abstract}


$\mathrm{mV}$. In control group, voltage across resistor did not change $(\mathrm{P}=0.9153)$ with time course and mean was $167.8 \pm 8.20 \mathrm{mV}$ ranged from 157 to 174.5 $\mathrm{mV}$ during $10 \mathrm{~d}$ operation. In $0.05 \%$ Saponin group, voltage across resistor increased $(\mathrm{P}<0.0001)$ after $\mathrm{d} 2$ and mean was $187.3 \pm 4.30 \mathrm{mV}$ ranged between 161.5 and $204.0 \mathrm{mV}$ and the $10 \mathrm{~d}$ mean of voltage across resistor in $0.05 \%$ Saponin was greater $(\mathrm{P}<0.0001)$ than in control group. 0.05\% Saponin also had greater voltage across resistor at $\mathrm{d} 5(\mathrm{P}=0.0030)$ and $\mathrm{d} 6(\mathrm{P}=0.0246)$ than control. End point potential increased $(\mathrm{P}<0.0001)$ in $0.05 \%$ Saponin after $\mathrm{d} 2.0 .05 \%$ Saponin had greater $(\mathrm{P}<0.05)$ end point potentials than control at $\mathrm{d} 1, \mathrm{~d} 4, \mathrm{~d} 7, \mathrm{~d} 10$, and also $10 \mathrm{~d}$ mean was greater (731.9 vs $606.5 \mathrm{mV} ; \mathrm{P}<$ $0.0001)$ in $0.05 \%$ Saponin. Power density increased $(\mathrm{P}<0.0001)$ after $\mathrm{d} 2$ in $0.05 \%$ Saponin. $0.05 \%$ Saponin MFCs had greater $(\mathrm{P}<0.05)$ power density than control at $\mathrm{d} 5$ and $\mathrm{d} 6$, and also a greater $(\mathrm{P}<0.0001)$ overall mean of $10 \mathrm{~d}$ operation. The current study provides strong background for potential use of saponin and saponin containing natural resources for methanogenesis inhibitor and cellulolysis enhancer in MFC and also cellulolysis reactors.

\section{Keywords}

Microbial Fuel Cells, Saponin, Bioenergy

\section{Introduction}

Fossil fuels represented about $80 \%$ of the global energy use [1], and fossil fuel combustion and natural gas and petroleum systems for energy contributed 95.3\% of greenhouse emission in the USA [2] which cause global warming and pollutions [3]. Therefore, development of technologies generating clean and sustainable energy to reduce fossil fuels usage has been undertaken [4]. Microbial fuel cell (MFC) is one of renewable biofuel production technology that directly converts biomass to electricity [5] MFC has shown tremendous electron donor versatility including simple substrates like glucose and organic acids [6] [7], complex substrates such as municipal and industrial wastewaters [8] [9]; and cellulosic biomass [10] [11].

Cellulosic biomass is particularly attractive renewable resources for its low cost and abundance [12] [13] and neutral carbon balance [14]. To utilize cellulosic biomass in MFC, the anodic process requires cellulose degradation, but electrochemically active microorganisms did not possess cellulolytic activity, thus cellulose fermentation by cellulolytic microorganisms is required as electron donors to generate electricity [15] [16]. Therefore, rumen fluid had been studied for MFCs because microorganisms in the rumen effectively hydrolyze cellulose and conserve energy via anaerobic respiration or fermentation [17]. However, methanogens in anaerobic microbial community contribute significantly to limiting cellulosic power generation in MFC. Methanogenesis diverts electron from the anode and methanogens act as substrate competitors to the exoelectrogens, acetoclastic methanogens compete for electron donors, and hy- 
drogenotrophic methanogens utilize the hydrogen produced in MFCs [18].

Supplementation of tea (Camellia sinensis) seed saponin [19], tea saponin extract [20] and saponin rich yucca schidigera extract [21] have shown methanogenesis inhibitions and also addition of saponin rich fractions from different plant materials [22] induced proliferation of fiber degrading bacteria on in vitro cultures of rumen microorganisms. Furthermore, improvement of power generation and methanogenesis reduction in MFC was reported with supplementation of bellflower (Platycodon grandifforum) root which is known to contain saponins [23]. However, direct effects of saponin on power generation and methane production in MFC had not been studied. Understanding of saponin effects on MFC efficacy would expand the potential use of saponin rich natural resources as MFC supplements.

Therefore, we hypothesized that addition of saponin would decrease methanogenesis and enhance the power generation from cellulose in MFCs. The objectives of the current study were 1) to investigate the direct effect of saponin on methanogenesis and power generation in MFC; and 2) consequently to provide rationale to expand the use of saponin rich natural resources in biofuel production.

\section{Materials \& Methods}

\subsection{Microbial Fuel Cell Construction}

H-type MFCs consisted two $125 \mathrm{~mL}$-volume glass bottles, anode and cathode. Two compartments joined at branched tube and cation exchange membrane (CMI-7000S, Membranes International Inc., NJ) was placed and clamped between branched tube. Two gram of finely ground pine tree (Avicel PH-101, Sigma-Aldrich) was weighed, $80 \mathrm{~mL}$ of culture medium and $20 \mathrm{~mL}$ strained rumen fluid were transferred into anode chamber, then well suspended using agitator. $100 \mathrm{~mL}$ of phosphate buffered saline $\mathrm{pH} 7.4$ (PBS) was transferred to cathode chamber. Electrodes (Graphite plates, $12 \mathrm{~cm}^{2}$ ) connected with copper wire was placed in the middle of anode and identical anode electrode of which copper wire was fixed to butyl rubber stopper was placed in anode chamber. Rubber stopper was placed on cathode but left open to air through tubing. Anode and cathode were connected externally through a copper wire with a resistor (300 $\mathrm{ohm})$. MFCs were placed in a water bath at $39^{\circ} \mathrm{C}$ for operation.

After 9d of MFC stabilization operation, two MFCs were randomly assigned to Saponin or Control groups and $5 \mathrm{mg}$ of Saponin (MFCD00081981, VWR) for Experiment 1 or $50 \mathrm{mg}$ of Saponin for Experiment 2 was added into anode chamber of treatment group. Control MFCs did not receive anything for Experiment 1 or 2 either. Two L-volume Mylar balloons were connected to each anode to collect biogas produced during experiment.

\subsection{Microorganisms and Culture Media}

For MFC anode compartment inoculum (anolyte), rumen fluid was collected from a dry dairy cow and while flushing of $\mathrm{CO}_{2}$ gas, filtered through 4 layers of cheesecloth to remove feed debris and transferred to an Erlenmeyer flask, then 
bubbled with $\mathrm{CO}_{2}$ gas for $10 \mathrm{~min}$ and closed with cotton ball and stored in an incubator at $39^{\circ} \mathrm{C}$ until inoculated to MFCs.

Culture medium containing $0.048 \% \mathrm{KH}_{2} \mathrm{PO}_{4}, 0.048 \% \mathrm{~K}_{2} \mathrm{HPO}_{4}, 0.048 \%\left(\mathrm{NH}_{4}\right)_{2} \mathrm{SO}_{4}$, $0.096 \% \mathrm{NaCl}, 0.5 \%$ Trypticase peptone, $5 \%$ yeast extract, $0.05 \%$ cysteine- $\mathrm{HCl}$, $0.013 \% \mathrm{CaCl}_{2} \cdot 2 \mathrm{H}_{2} \mathrm{O}, 0.02 \% \mathrm{MgSO}_{4} \cdot 7 \mathrm{H}_{2} \mathrm{O}, 0.4 \% \mathrm{Na}_{2} \mathrm{CO}_{3}, 0.1 \%$ sodium fumarate, and $1 \mathrm{ppm}$ of resazurin, was prepared anaerobically and autoclaved at $121^{\circ} \mathrm{C}$ for $30 \mathrm{~min}$ and stored at room temperature. Phosphate buffered saline pH7.4 (PBS) consisted of $137 \mathrm{mM} \mathrm{NaCl}, 2.7 \mathrm{mM} \mathrm{KCl}, 10 \mathrm{mM} \mathrm{Na}_{2} \mathrm{HPO}_{4}$, and $2 \mathrm{mM} \mathrm{KH}_{2} \mathrm{PO}_{4}$ [24] and was autoclaved at $121^{\circ} \mathrm{C}$ for $30 \mathrm{~min}$ and stored at room temperature.

\subsection{Measurements and Calculation}

Voltage across a resistor (closed circuit voltage), open circuit voltage, and current were measured daily using a digital multimeter, for 10d. The power density normalized to electrode surface area was calculated using following equations:

$$
P=\frac{I V}{A} \text { and } I=\frac{V}{R},
$$

where, $I(A)$ is the current, $V(V)$ is voltage, $R(\mathrm{ohm})$ is the external resistance, and $A\left(\mathrm{~m}^{2}\right)$ is the projected area of the anode.

On d10, the volume of biogases produced in anode collected in Mylar balloons were measured using a $250 \mathrm{~mL}$ glass syringe. Gas components were analyzed using an Agilent 6890 series gas chromatograph equipped with a thermal conductivity detector and a packed column prepared with 60/80 Carboxen 1000 (12390-U Supelco, Sigma-Aldrich). Argon gas flow rate was $20 \mathrm{ml} / \mathrm{min}$ and the injector and detector temperatures were $250^{\circ} \mathrm{C}$ for both. Oven temperature ramped between $50^{\circ} \mathrm{C}$ and $150^{\circ} \mathrm{C}$.

\subsection{Statistical Analyses}

The treatments included 2 doses of saponin, $0.005 \%$ and $0.05 \%(\mathrm{w} / \mathrm{v})$. Experiment 1 (Exp 1) was conducted with duplication of $0.005 \%$ MFCs and control MFCs. Experiment $2(\operatorname{Exp} 2)$ was done in the same conditions but with $0.05 \%$ dose and control MFCs after Exp 1 was completed. Effects of each dose of saponin was compared to only controls in the same experiment.

Electricity generation, fermentation gas production and gas composition were analyzed using the one way ANOVA procedure of JPM 14.1.0 (SAS Institute Inc.). When the effect was significant $(\mathrm{P}<0.05)$, means between treatments were separated using Student's t-test $(P<0.05)$.

\section{Results}

\subsection{Biogases Production}

Experiment 1. Methane and carbon dioxide productions during 10d MFC operation were not different between control and 0.005\% Saponin (Figure 1: Exp1). Total gas volume and methane to carbon dioxide ratio were also similar between treatments. 
Experiment 2. Supplementation of Saponin at $0.05 \%$ increased $(\mathrm{P}<0.05)$ carbon dioxide and total gas production and decreased $(\mathrm{P}<0.05)$ methane production and methane to carbon dioxide ratio during 10d MFC operation (Figure 1: Exp2). Methane reduction was $20 \mathrm{~mL}$ which is $9.7 \%$ of production in control and increased carbon dioxide was $40.3 \mathrm{~mL}$ which is $37.2 \%$ of production in control by $0.05 \%$ Saponin.

\subsection{Power Generation}

Experiment 1. Voltage across resistor prior to treatment addition (d0) was 172.8 $\pm 7.14 \mathrm{mV}$. Voltage across resistor (Table 1) were steady with time course for both control $(\mathrm{P}=0.3412)$ and $0.005 \%$ Saponin $(\mathrm{P}=0.3803)$. Average of voltage across resistor were similar $(\mathrm{P}=0.6561)$ between treatments and values were $172.0 \pm 4.51$ and $172.9 \pm 4.02 \mathrm{mV}$ for control and $0.005 \%$ Saponin, respectively, although $0.005 \%$ Saponin had lower $(\mathrm{P}=0.0377)$ voltage at $\mathrm{d} 9$.

End point potential (Table 2; open circuit voltage) increased with time in both control $(\mathrm{P}=0.0007)$ and $0.005 \%$ Saponin $(\mathrm{P}=0.0037)$. Between treatments, $0.005 \%$ Saponin had the greater $(614$ vs $602 \mathrm{mV}$; $\mathrm{P}=0.0330)$ end point potential than control at $\mathrm{d} 4$, however overall means were not different $(\mathrm{P}=0.7304)$ between treatments.
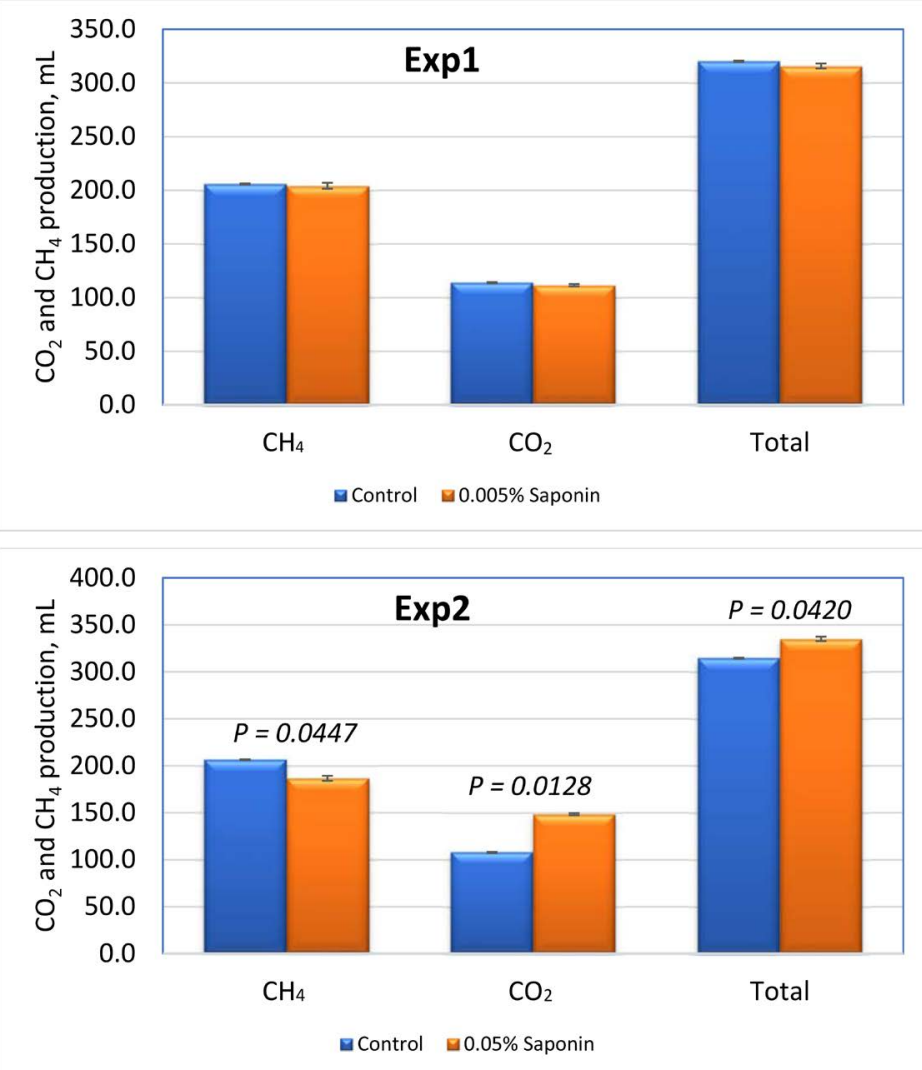

Figure 1. Accumulated gas production on d10 of operation in the anode compartment of MFCs. MFCs were built with $20 \%$ rumen fluid as inocula and $2 \%$ of cellulose (Avicel ${ }^{\circledR}$ ) with or without saponin at $0.001 \%(\operatorname{Exp} 1)$ or $0.01 \%(\operatorname{Exp} 2)$. 
Table 1. Closed circuit voltage across $300 \mathrm{ohms}$ resistor measured from microbial fuel cells built with $20 \%$ rumen fluid as inocula and $2 \%$ of cellulose $\left(\right.$ Avicel $\left.^{\circledR}\right)$ with or without saponin at $0.005 \%(\operatorname{Exp} 1)$.

\begin{tabular}{ccccc}
\hline Day & Control & 0.005\% Saponin & SEM $^{1}$ & $\mathbf{P}^{2}$ \\
\hline 0 & 160.5 & 167.0 & 2.06 & 0.0876 \\
1 & 174.5 & 173.0 & 2.25 & 0.8075 \\
3 & 177.5 & 181.0 & 1.44 & 0.2965 \\
4 & 166.5 & 175.0 & 2.59 & 0.0541 \\
5 & 177.5 & 173.0 & 1.65 & 0.2137 \\
6 & 170.0 & 177.0 & 4.79 & 0.5799 \\
7 & 174.5 & 167.0 & 2.29 & 0.0532 \\
8 & 174.5 & 175.5 & 1.87 & 0.8457 \\
9 & 169.5 & 174.0 & 4.99 & 0.7396 \\
10 & 175.0 & 167.5 & 2.25 & 0.0377 \\
SEM $^{1}$ & 172.5 & 172.0 & 3.47 & 0.9584 \\
$\mathrm{P}^{3}$ & 4.5054 & 4.0170 & & \\
\hline
\end{tabular}

${ }^{1}$ Standard error of means. ${ }^{2} \mathrm{P}$-value; probabilities that treatments effect is not significant within the day. ${ }^{3} \mathrm{P}$-value; probabilities that day effect is not significant within the treatment.

Table 2. End point potential measured from microbial fuel cells built with $20 \%$ rumen fluid as inocula and $2 \%$ of cellulose (Avicel ${ }^{\circledR}$ ) with or without saponin at $0.005 \%$ (Exp1).

\begin{tabular}{ccccc}
\hline Day & Control & 0.005\% Saponin & SEM $^{1}$ & $\mathbf{P}^{2}$ \\
\hline 0 & 595.0 & 576.5 & 5.75 & 0.0712 \\
1 & 571.5 & 571.0 & 8.86 & 0.9837 \\
2 & 561.5 & 565.0 & 4.70 & 0.7849 \\
3 & 555.5 & 564.0 & 3.09 & 0.2065 \\
4 & 602.0 & 614.0 & 3.58 & 0.0330 \\
5 & 609.5 & 596.5 & 8.95 & 0.5809 \\
6 & 624.0 & 618.0 & 2.71 & 0.3604 \\
7 & 599.5 & 604.5 & 10.45 & 0.8619 \\
8 & 627.5 & 623.5 & 7.64 & 0.8489 \\
9 & 631.0 & 624.0 & 5.44 & 0.6285 \\
10 & 643.0 & 630.0 & 5.39 & 0.3041 \\
SEM $^{1}$ & 9.9109 & 10.5356 & & \\
$\mathrm{P}^{3}$ & 0.0007 & 0.0037 & & \\
\hline
\end{tabular}

${ }^{1}$ Standard error of means. ${ }^{2} \mathrm{P}$-value; probabilities that treatments effect is not significant within the day. ${ }^{3} \mathrm{P}$-value; probabilities that day effect is not significant within the treatment.

Power density (Figure 2: Exp 1) in either control group $(\mathrm{P}=0.3548)$ and $0.005 \%$ Saponin $(\mathrm{P}=0.3869)$ did not go up or down through time course during 
10d operation. $0.005 \%$ Saponin had smaller $(P=0.0363)$ power density than control at $\mathrm{d} 9$, but $10 \mathrm{~d}$ means $(\mathrm{P}=0.6661)$ were 57.5 and $58.0 \mathrm{~mW} / \mathrm{m}^{2}$ for control and $0.005 \%$ Saponin, respectively.

Experiment 2. Voltage across resistor prior to treatment addition (d0) was $164.75 \pm 9.07 \mathrm{mV}$. In control group, voltage across resistor (Table 3 ) did not change $(\mathrm{P}=0.9153)$ with time course and mean was $167.8 \pm 8.20 \mathrm{mV}$ ranged from 157 to $174.5 \mathrm{mV}$ during 10d operation. In $0.05 \%$ Saponin group, voltage across resistor increased $(\mathrm{P}<0.0001)$ after $\mathrm{d} 2$ and mean was $187.3 \pm 4.30 \mathrm{mV}$ ranged between 161.5 and $204.0 \mathrm{mV}$. This $10 \mathrm{~d}$ mean of voltage across resistor in $0.05 \%$ Saponin was greater $(\mathrm{P}<0.0001)$ than in control group. $0.05 \%$ Saponin also had greater voltage across resistor at $\mathrm{d} 5(\mathrm{P}=0.0030)$ and $\mathrm{d} 6(\mathrm{P}=0.0246)$ than control.

End point potential (Table 4$)$ in control did not change $(\mathrm{P}=0.7094)$ with

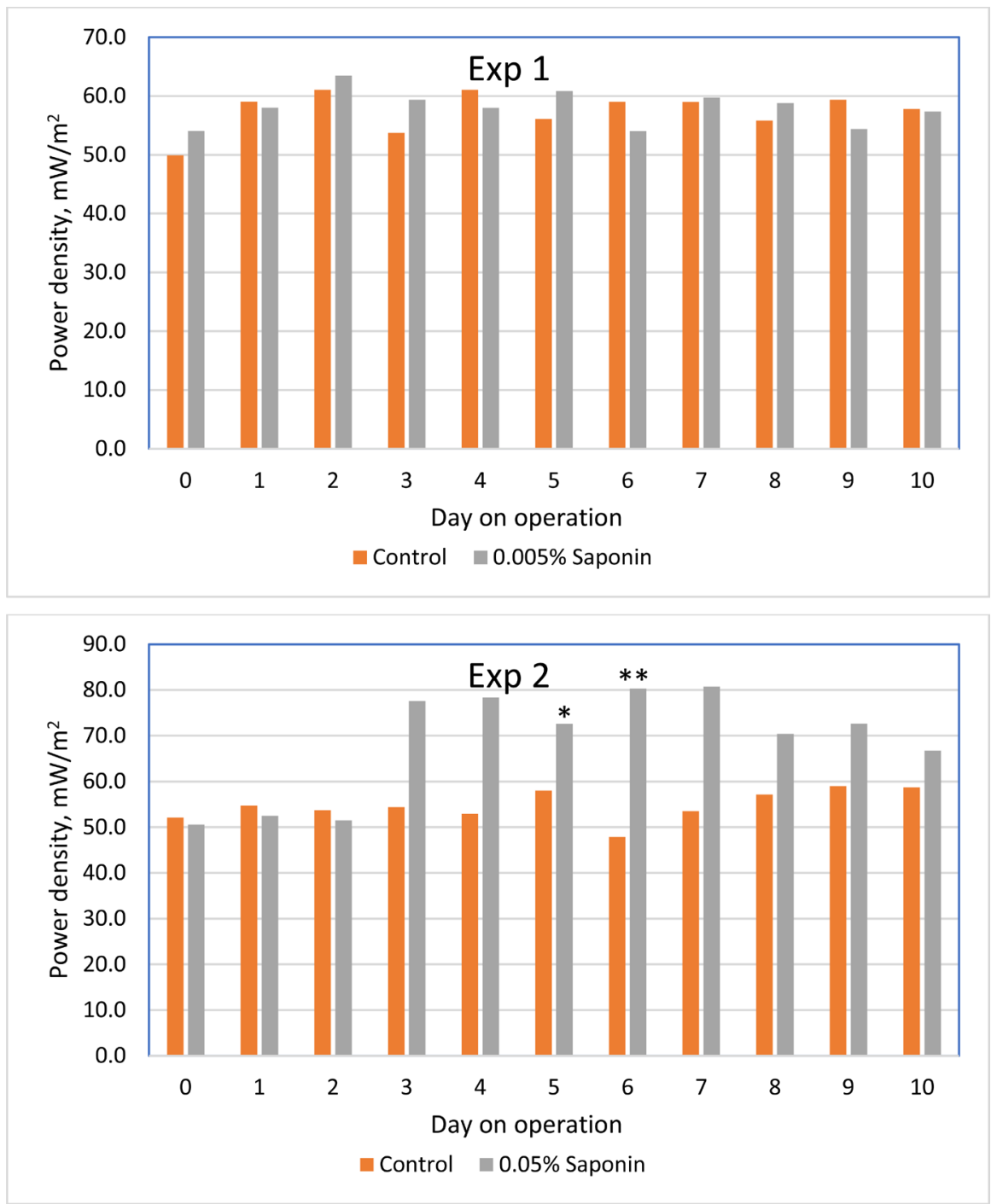

Figure 2. Power density measured from MFCs built with $20 \%$ rumen fluid as inocula and $2 \%$ of cellulose $\left(\right.$ Avicel $\left.{ }^{\circledR}\right)$ with or without saponin at $0.005 \%\left(\right.$ Exp1) or $0.05 \%(\operatorname{Exp} 2) .{ }^{\star} \mathrm{P}$ $<0.05 ;{ }^{* *} \mathrm{P}<0.01$. 
Table 3. Closed circuit voltage across $300 \mathrm{ohms}$ resistor measured from microbial fuel cells built with $20 \%$ rumen fluid as inocula and $2 \%$ of cellulose (Avicel ${ }^{\circledR}$ ) with or without saponin at $0.05 \%(\operatorname{Exp} 2)$.

\begin{tabular}{ccccc}
\hline Day & Control & $0.05 \%$ Saponin & SEM $^{1}$ & $\mathbf{P}^{2}$ \\
\hline 0 & 163.5 & 161.5 & 5.14 & 0.8877 \\
1 & 168.0 & 164.5 & 2.69 & 0.6242 \\
2 & 166.0 & 163.0 & 4.99 & 0.8265 \\
4 & 167.0 & 200.0 & 10.84 & 0.1209 \\
5 & 165.0 & 201.0 & 11.29 & 0.0796 \\
6 & 173.0 & 193.5 & 5.94 & 0.0030 \\
7 & 157.0 & 203.5 & 13.76 & 0.0246 \\
8 & 166.0 & 204.0 & 11.80 & 0.0701 \\
9 & 171.5 & 190.5 & 6.82 & 0.1957 \\
10 & 174.5 & 193.5 & 5.82 & 0.0570 \\
$\mathrm{SEM}^{1}$ & 174.0 & 185.5 & 4.13 & 0.1963 \\
$\mathrm{P}^{3}$ & 8.1951 & 4.3038 & & \\
\hline
\end{tabular}

${ }^{1}$ Standard error of means. ${ }^{2} \mathrm{P}$-value; probabilities that treatments effect is not significant within the day. ${ }^{3} \mathrm{P}$-value; probabilities that day effect is not significant within the treatment.

Table 4. End point potential measured from microbial fuel cells built with $20 \%$ rumen fluid as inocula and $2 \%$ of cellulose $\left(\right.$ Avicel $\left.^{\circledR}\right)$ with or without saponin at $0.05 \%$ (Exp2).

\begin{tabular}{ccccc}
\hline Day & Control & 0.05\% Saponin & SEM $^{1}$ & $\mathrm{P}^{2}$ \\
\hline 0 & 575.5 & 565.0 & 10.26 & 0.7045 \\
1 & 606.0 & 688.0 & 24.04 & 0.0154 \\
2 & 529.5 & 613.5 & 25.69 & 0.0562 \\
3 & 615.0 & 812.0 & 63.69 & 0.1071 \\
4 & 619.0 & 771.0 & 45.01 & 0.0250 \\
5 & 612.5 & 715.5 & 36.35 & 0.1820 \\
6 & 646.5 & 754.0 & 40.23 & 0.2286 \\
7 & 616.0 & 784.0 & 49.65 & 0.0233 \\
8 & 593.0 & 775.5 & 58.84 & 0.1046 \\
9 & 622.0 & 751.5 & 39.45 & 0.0523 \\
10 & 636.5 & 821.0 & 54.04 & 0.0144 \\
$\mathrm{SEM}^{1}$ & 38.1245 & 17.75 & & \\
$\mathrm{P}^{3}$ & 0.7094 & $<0.0001$ & & \\
\hline
\end{tabular}

${ }^{1}$ Standard error of means. ${ }^{2} \mathrm{P}$-value; probabilities that treatments effect is not significant within the day. ${ }^{3} \mathrm{P}$-value; probabilities that day effect is not significant within.

time course, however it increased $(\mathrm{P}<0.0001)$ in $0.05 \%$ Saponin after $\mathrm{d} 2$. Between treatments, $0.05 \%$ Saponin had greater $(\mathrm{P}<0.05)$ end point potentials 
than control at d1, d4, d7, d10, and also $10 \mathrm{~d}$ mean was greater (731.9 vs 606.5 $\mathrm{mV}$; $\mathrm{P}<0.0001)$ in $0.05 \%$ Saponin.

Power density (Figure 2: Exp 2) had similar trends for each group. It did not change $(\mathrm{P}=0.9204)$ with time course in control group, but increased $(\mathrm{P}<$ $0.0001)$ after $\mathrm{d} 2$ in $0.05 \%$ Saponin. $0.05 \%$ Saponin MFCs had greater $(\mathrm{P}<0.05)$ power density than control at $\mathrm{d} 5$ and $\mathrm{d} 6$, and also a greater $(\mathrm{P}<0.0001)$ overall mean of $10 \mathrm{~d}$ operation.

\section{Discussion and Conclusion}

Methane inhibition with supplementation of saponin extracted from tea (Camellia sinensis) seed to in vitro rumen culture was reported [19] and in their fermentation system, methane production decreased linearly with dose of saponin up to $0.8 \%$ of substrate, which is equivalent to $0.005 \%(\mathrm{w} / \mathrm{v})$ of in vitro culture. Another study [20], where inhibited methanogenesis and increased cellulolytic bacteria Fibrobacter succinogenes, included $0.4 \%$ of tea saponin in rumen fluid or pure culture. In the current study, anolyte for MFCs were $20 \%$ rumen fluid and substrates (electron donor) were $2 \%$ cellulose (finely ground pine tree), and saponin was added at the dose of $0.005 \%$ and $0.05 \%$ (w/v). Addition of $0.005 \%$ saponin did not modify the biogas production or methanogenesis while $0.05 \%$ of saponin decreased methanogenesis and increased carbon dioxide production. Therefore, the strong evidence of saponin effects in MFCs was observed from this study and the minimal effective dose of saponin can be deduced between $0.005 \%$ and $0.05 \%$. While $20 \mathrm{~mL}$ of methane decreased, $40 \mathrm{~mL}$ of carbon dioxide increased with $0.05 \%$ saponin addition. As a result of carbohydrate fermentation, even in anaerobic digestion ending with short chain fatty acids such as acetate, propionate and butyrate, the increase in carbon dioxide reflects the increase in substrates fermentation because of the identical carbon balance between methane and carbon dioxide. Increase in cellulolysis with $0.05 \%$ saponin can be inferred because substrate was cellulose, and it may coincide with the proliferation of cellulolytic bacteria with saponin addition [19]. Methanogenesis does not only divert electron from the anode but also cause the competition of methanogens for substrates to exoelectrogens which transfer electrons to anode [18]. Aacetoclastic methanogens compete for electron donors $\left(\mathrm{CH}_{3} \mathrm{COO}^{-}+\mathrm{H}^{+} \rightarrow \mathrm{CH}_{4}+\mathrm{CO}_{2}\right)$ and hydrogenotrophic methanogens utilize the hydrogen produced in the anode of MFC $\left(4 \mathrm{H}_{2}+\mathrm{CO}_{2} \rightarrow \mathrm{CH}_{4}+2 \mathrm{H}_{2} \mathrm{O}\right)$, and methanogenesis consumes exogenous energy, thus it is certainly not favorable for exoelectrogens establishment on anode which is critical in electricity generation in MFC. Therefore, improved power generation in MFC is expected with methane inhibition.

In experiment 1 , the power generation was constant during $10 \mathrm{~d}$ operation which reflected steady fermentation of cellulose in both control and $0.005 \%$ saponin added MFC, and no difference in energy production was observed with $0.005 \%$ saponin supplementation. At this dose, saponin did not show any effect on microorganism involved cellulolysis, methanogenesis or electron transferring 
to anode in MFC although this dose or less was reported effective in animal studies. In experiment 2 , saponin concentration was increased to $0.05 \%$ to observe the effects on MFC productivity. The end point potential increased with $0.05 \%$ saponin comparing to control as early as $\mathrm{d} 1$. Improvement in power generation was observed not only at MFC operation time points but also through $10 \mathrm{~d}$ means with $0.05 \%$ saponin addition. The difference of $10 \mathrm{~d}$ mean of power density is $13.8 \mathrm{~mW} / \mathrm{m}^{2}$ ( 54.7 vs $68.5 \mathrm{~mW} / \mathrm{m}^{2}$ ) which is $25.2 \%$ of power density in control, however the accumulated differences measured daily for $10 \mathrm{~d}$ is 151.7 $\mathrm{mW} / \mathrm{m}^{2}$ which is equivalent to $277.2 \%$ of average of power density in control. Electricity generation is continuous in MFC while experimental observation was once a day, therefore the improvement in electricity generation presented might be underestimated. Various natural resources consist saponin and some of its by-products are also known to contain saponin such as ginseng marc. The current study provides strong background for potential use of saponin and saponin containing natural resources for methanogenesis inhibitor and cellulolysis enhancer in MFC and also cellulolysis reactors.

Microbial Fuel Cell is a technology that generates clean sustainable bioenergy from cellulosic biomass including municipal wastewater and industrial organic waste. However, methanogenesis remains as a major factor limiting MFC performance. In the current study, rumen microorganisms were employed as anolyte and cellulose served as electron donors in MFC, and 0.05\% (w/v) saponin addition improved the cellulose fermentation and the electricity generation, and inhibited the methanogenesis. Results from the current study elucidate the effects of saponin rich resource on cellulose fermentation and imply that application of saponin and saponin containing natural resource would be beneficial to maximize the methanogenesis inhibition and power generation from cellulosic biomass in MFCs.

\section{Acknowledgements}

The authors acknowledge the Fuzbien Technology Institute and Youth with Talents for sponsoring this research project (FTI-2020-8).

\section{Conflicts of Interest}

The authors declare no conflicts of interest regarding the publication of this paper.

\section{References}

[1] Goldemberg, J. and Johansson, T.B. (2004) World Energy Assessment Overview: 2004 Update. United Nations Development Programme, New York.

[2] EPA (2018) Inventory of U.S. Greenhouse Gas Emissions and Sinks: 1990-2018. https://www.epa.gov/ghgemissions/inventory-us-greenhouse-gas-emissions-and-sin ks-1990-2018

[3] Saratale, G. and Oh, S. (2011) Production of Thermotolerant and Alkalotolerant Cellulolytic Enzymes by Isolated Nocardiopsis sp. KNU. Biodegradation, 22, 
905-919. https://doi.org/10.1007/s10532-010-9450-0

[4] Levin, D.B., Islam, R., Cicek, N. and Sparling, R. (2006) Hydrogen Production by Clostridium Thermocellum 27405 from Cellulosic Biomass Substrates. International Journal of Hydrogen Energy, 31, 1496-1503.

https://doi.org/10.1016/j.ijhydene.2006.06.015

[5] Logan, B.E. and Regan, J.M. (2006) Microbial Fuel Cells-Challenges and Applications. Environmental Science \& Technology, 40, 5172-5180. https://doi.org/10.1021/es0627592

[6] Bond, D.R. and Lovley, D.R. (2003) Electricity Production by Geobacter sulfurreducens Attached to Electrodes. Applied and Environmental Microbiology, 69, 1548-1555. https://doi.org/10.1128/AEM.69.3.1548-1555.2003

[7] Liu, H., Cheng, S. and Logan, B.E. (2005) Production of Electricity from Acetate or Butyrate Using a Single-Chamber Microbial Fuel Cell. Environmental Science \& Technology, 39, 658-662. https://doi.org/10.1021/es048927c

[8] Min, B., Kim, J., Oh, S., Regan, J.M. and Logan, B.E. (2005) Electricity Generation from Swine Wastewater Using Microbial Fuel Cells. Water Research, 39, 4961-4968. https://doi.org/10.1016/j.watres.2005.09.039

[9] Aelterman, P., Rabaey, K., Clauwaert, P. and Verstraete, W. (2006) Microbial Fuel Cells for Wastewater Treatment. Water Science and Technology, 54, 9-15. https://doi.org/10.2166/wst.2006.702

[10] Hassan, S.H., Kim, Y.S. and Oh, S.E. (2012) Power Generation from Cellulose Using Mixed and Pure Cultures of Cellulose-Degrading Bacteria in a Microbial Fuel Cell. Enzyme and Microbial Technology, 51, 269-273. https://doi.org/10.1016/j.enzmictec.2012.07.008

[11] Ishii, S., Suzuki, S., Norden-Krichmar, T.M., Nealson, K.H., Sekiguchi, Y. and Gorby, Y.A. (2012) Functionally Stable and Phylogenetically Diverse Microbial Enrichments from Microbial Fuel Cells during Wastewater Treatment. PLoS ONE, 7, e30495. https://doi.org/10.1371/journal.pone.0030495

[12] Lynd, L.R., Weimer, P.J., van Zyl, W.H. and Pretorius, I.S. (2002) Microbial Cellulose Utilization: Fundamentals and Biotechnology. Microbiology and Molecular Biology Reviews, 66, 506-577. https://doi.org/10.1128/MMBR.66.3.506-577.2002

[13] Schwarz, W.H. (2001) The Cellulosome and Cellulose Degradation by Anaerobic Bacteria. Applied Microbiology and Biotechnology, 56, 634-649. https://doi.org/10.1007/s002530100710

[14] Niessen, J., Schröder, U., Harnisch, F. and Scholz, F. (2005) Gaining Electricity from in Situ Oxidation of Hydrogen Produced by Fermentative Cellulose Degradation. Letters in Applied Microbiology, 41, 286-290. https://doi.org/10.1111/j.1472-765X.2005.01742.x

[15] Desvaux, M., Guedon, E. and Petitdemange, H. (2000) Cellulose Catabolism by Clostridium cellulolyticum Growing in Batch Culture on Defined Medium. Applied and Environmental Microbiology, 66, 2461-2470. https://doi.org/10.1128/AEM.66.6.2461-2470.2000

[16] Lovley, D.R. (2006) Bug Juice: Harvesting Electricity with Microorganisms. Nature Reviews Microbiology, 4, 497-508. https://doi.org/10.1038/nrmicro1442

[17] Krause, D.O., Denman, S.E., Mackie, R.I. and Morrison, M. (2003) Opportunities to Improve Fiber Degradation in the Rumen: Microbiology, Ecology, and Genomics. FEMS Microbiology Reviews, 27, 663-693. https://doi.org/10.1016/S0168-6445(03)00072-X 
[18] Rago, L., Guerrero, J., Baeza, J.A. and Guisasola, A. (2015) 2-Bromoethanesulfonate Degradation in Bioelectrochemical Systems. Bioelectrochemistry, 105, 44-49. https://doi.org/10.1016/j.bioelechem.2015.05.001

[19] Jadhav, R.V., Kannan, A., Bhar, R., Sharma, O.P., Gulati, A., Rajkumar, K., Mal, G., Singh, B. and Verma, M.R. (2018) Effect of Tea (Camellia sinensis) Seed Saponins on in Vitro Rumen Fermentation, Methane Production and True Digestibility at Different Forage to Concentrate Ratios. Journal of Applied Animal Research, 46, 118-124. https://doi.org/10.1080/09712119.2016.1270823

[20] Guo, Y.Q., Liu, J.-X., Lu, Y., Zhu, W.Y., Denman, S.E. and McSweeney, C.S. (2008) Effect of Tea Saponin on Methanogenesis, Microbial Community Structure and Expression of mcrA Gene, in Cultures of Rumen Microorganisms. Letters in Applied Microbiology, 47, 421-426. https://doi.org/10.1111/j.1472-765X.2008.02459.x

[21] Wang, C.J., Wang, S.P. and Zhou, H. (2009) Influences of Flavomycin, Ropadiar, and Saponin on Nutrient Digestibility, Rumen Fermentation, and Methane Emission from Sheep. Animal Feed Science and Technology, 148, 157-166. https://doi.org/10.1016/j.anifeedsci.2008.03.008

[22] Goel, G., Makkar, H.P.S. and Becker, K. (2008) Changes in Microbial Community Structure, Methanogenesis and Rumen Fermentation in Response to Saponin-Rich Fractions from Different Plant Materials. Journal of Applied Microbiology, 105, 770-777. https://doi.org/10.1111/j.1365-2672.2008.03818.x

[23] Park, J.-I., Kim, H., Go, D.K., Park, P.S., Lee, S.H., Koh, M.J., Jo, J., Lee, D., Lee, S. and Chung, P.S. (2019) Enhancement of Power Generation in Microbial Fuel Cells through Supplementation of Platycodon grandiflorum in Doraji Roots. Journal of Sustainable Bioenergy Systems, 9, 169-178. https://doi.org/10.4236/jsbs.2019.94011

[24] Goering, H.K. and Van Soest, P.J. (1970) Forage Fiber Analyses (Apparatus, Reagents, Procedures, and Some Applications). USDA-ARS Agric. Handbook No. 379, Washington DC. 